Article

\title{
Functional Feeding Groups of Macrofauna and Detritus Decomposition along a Gradient of Glacial Meltwater Influence in Tropical High-Andean Streams
}

\author{
Patricio Andino ${ }^{1}$, Rodrigo Espinosa ${ }^{1,2}$ (), Verónica Crespo-Pérez ${ }^{1}$, Sophie Cauvy-Frauníe ${ }^{3}$, Olivier Dangles ${ }^{4}$ \\ and Dean Jacobsen ${ }^{5, *}$ \\ 1 Laboratorio de Limnología, Museo QCAZ I, Escuela de Ciencias Biológicas, Pontificia Universidad Católica \\ del Ecuador, Av. 12 de Octubre 1076 y Roca, Apartado, Quito 17-01-2184, Ecuador; \\ puchitricio@gmail.com (P.A.); rodrigo.espinosa@ikiam.edu.ec (R.E.); verocrespoperez@gmail.com (V.C.-P.) \\ 2 Grupo de Biogeografía y Ecología Espacial—BioGeoE2, Facultad de Ciencias de la Vida, Universidad \\ Regional Amazónica Ikiam, Tena 150150, Ecuador \\ 3 Centre de Lyon-Villeurbanne, UR RIVERLY, INRAE, 69625 Villeurbanne, France; \\ sophie.cauvy-fraunie@irstea.fr \\ 4 Centre d'Ecologie Fonctionnelle et Evolutive, Institut de Recherche pour le Développement (IRD), Université \\ de Montpellier, CNRS, EPHE, IRD, 34199 Montpellier, France; olivier.dangles@ird.fr \\ 5 Freshwater Biological Section, Department of Biology, University of Copenhagen, \\ DK-2100 Copenhagen, Denmark \\ * Correspondence: djacobsen@bio.ku.dk
}

\section{check for} updates

Citation: Andino, P.; Espinosa, R.; Crespo-Pérez, V.; Cauvy-Frauníe, S.; Dangles, O.; Jacobsen, D. Functional Feeding Groups of Macrofauna and Detritus Decomposition along a Gradient of Glacial Meltwater Influence in Tropical High-Andean Streams. Water 2021, 13, 3303. https://doi.org/10.3390/w13223303

Academic Editor: Marina Marcella Manca

Received: 18 October 2021

Accepted: 17 November 2021

Published: 22 November 2021

Publisher's Note: MDPI stays neutral with regard to jurisdictional claims in published maps and institutional affiliations.

Copyright: (c) 2021 by the authors. Licensee MDPI, Basel, Switzerland. This article is an open access article distributed under the terms and conditions of the Creative Commons Attribution (CC BY) license (https:/ / creativecommons.org/licenses/by/ $4.0 /)$.
Abstract: Tropical Andean glaciers are retreating rapidly, with possible consequences for trophic structure and ecosystem processes in high Andean meltwater streams. Here, we measured the environmental characteristics, quantified pools of particulate organic matter (POM) and periphyton (Chl. a), sampled benthic macroinvertebrates, determined functional feeding groups (FFG), and performed mesh bag decomposition experiments with Calamagrostis grass detritus at 17 stream sites along a gradient of glacial influence (GI) with $0-23 \%$ glacier cover in the catchment at 4050-4200 m a.s.l. in the Andes of Ecuador. POM was unrelated to GI while Chl. a. showed a weak (non-significant) negative relationship to GI. The macrofauna abundance decreased while taxon richness and the number of FFGs per site showed a hump-shaped relationship with increasing GI. Taxa with an opportunistic and generalist feeding mode generally dominated benthic assemblages and were related to high GI levels and low Chl. a. Only shredders were negatively related to GI, but unrelated to POM. Decomposition rates were comparable to those found in temperate alpine streams, and for both fine (0.0010-0.0065; median $\left.0.0028 \mathrm{~d}^{-1}\right)$ and coarse (0.0019-0.0088; median $\left.0.0048 \mathrm{~d}^{-1}\right)$ mesh bags, peaked at intermediate GI values, while the difference between bag types was small and almost constant along the GI gradient. This indicates an overall minor effect of macroinvertebrate shredders compared to that of microbes, in particular at high GI. It also suggests that the relatively high average temperature of these high-altitude equatorial streams $\left(7-10^{\circ} \mathrm{C}\right)$ does not produce higher decomposition rates than those in comparable but colder streams at temperate latitudes. The results suggest that, at the lower end of glacier cover, tropical glacier loss will not change the dominant microbial role in detritus decomposition, but that part of the physical abrasion could be partially replaced by biological shredding.

Keywords: Andes; tropical alpine streams; glacier influence; glacial retreat; benthic fauna; macroinvertebrates; functional feeding groups; decomposition

\section{Introduction}

Streams fed by glacial meltwater are notoriously harsh environments that generally have low average temperature, nutrient concentration, electrical conductivity, and physical stability, but high turbidity due to suspended solids [1]. Such harsh conditions 
act as environmental filters excluding many aquatic species from these habitats, and are thus important in structuring the composition of natural aquatic communities [2]. For example, the density and taxon richness of benthic macroinvertebrates usually decrease with increasing glacial cover in the catchment or proportion of discharge originating from glacial meltwater [3-5]. The distribution of biological and functional traits such as feeding habits of macroinvertebrates also show relationships with the degree of glacial influence in streams [6-9]. For example, the degree of omnivory seems to consistently increase with glacial influence [10-12] due to the considerable feeding plasticity of groups dominating glacier-fed streams [13].

Even though in-stream primary production from algae is usually low, this nevertheless seems to be the main energy basis for the food web in glacier-fed streams, with even lesser importance of allochthonous detritus $[10,14,15]$. Furthermore, studies on input and decomposition of allochthonous detritus have shown that leaf breakdown rates in glacier-fed streams in the Alps vary widely among sites with different glacial influence [16-18], reflecting site-specific differences in habitat characteristics and in macroinvertebrate shredder density and fungal composition [19].

Glaciers are retreating worldwide [20-22], with profound effects on flow regime and environmental conditions in meltwater-fed streams [23,24]. These changes are expected to lead to shifts in biological communities and ecological function in downstream systems [25-29]. During recent decades, a number of space-for-time substitutions, but also a handful of diachronic long-term studies have documented changes in macroinvertebrate communities as a direct result of glacial retreat [30-34]. However, changes in taxonomic community composition do not necessarily reveal shifts in the ecological function of these communities [35].

Relatively little is known about the ecology of glacier-fed streams in tropical mountains, but overall spatial patterns of macroinvertebrate community structure and diversity seem to follow what is known from temperate-Arctic latitudes [36-38]. Additionally, prominent functional traits such as feeding habits and the relationships between functional traits and glacial influence seem to be largely comparable between temperate and tropical glacier-fed streams, with functional diversity lower than expected from a null model close to glaciers [39]. To our knowledge, however, no study on stream ecosystem processes such as terrestrial leaf litter breakdown along gradients in glacial influence has been performed in tropical high alpine catchments, and therefore was the main focus of the present study. Marked differences in hydrological and other environmental characteristics exist among alpine and glacier-fed streams at different latitudes. For example, at high latitudes, glacier-fed streams show high seasonality in runoff and are surrounded by sparse terrestrial vegetation and thus input of allochthonous detritus, while at the equator, with little seasonality, the main flow variation in glacier-fed streams occurs on a diel basis, and streams are often surrounded by lush grass and bush vegetation [40,41]. Such differences may imply differences in ecological function between temperate and tropical glacier-fed streams.

Here, we studied functional feeding modes of macroinvertebrates and their relationship to primary food resources and decomposition of terrestrial detritus in small streams along a gradient of glacial meltwater influence in a tropical catchment in the high Andes of Ecuador. Our study is thus a space-for-time substitution contributing to the understanding and prediction of the possible future consequences of climate warming and glacier loss on trophic structure and function on tropical, glacier-fed streams. Specifically, our objectives were to (1) identify the relationship between glacier influence and quantities of primary food resources (particulate organic matter and periphyton); (2) examine distribution patterns of macroinvertebrate functional feeding groups (FFG) in relation to food sources and glacial influence; and (3) determine the decomposition rates of terrestrial grass detritus along the gradient of glacial influence, and assess the links with specific environmental factors and macroinvertebrate FFGs. Our hypotheses were (1) that quantities of primary food resources would decline with glacial influence; (2) that generalist FFGs would dominate at high levels of glacial influence; and (3) that the decomposition rate 
of detritus would be negatively related to glacial influence, both the microbial and the macroinvertebrate-mediated part.

\section{Materials and Methods}

\subsection{Study Area}

The field work was carried out between March and May of 2014 in 17 stream sites located on the western slopes of the ice-capped Antisana volcano, in the Ecuadorian Andes (Figures 1 and 2). Most of the sites coincided with those used by [39] in their study of functional structure invertebrate communities. However, our sites focused on the decomposition of terrestrial detritus, and spanned a narrower gradient in glacial influence and covered from 0 to $23 \%$ of glacier cover in the catchment, and thus did not include the sites closest to the glaciers. Additionally, our study sites were located within a narrow altitudinal band between 4040 and $4200 \mathrm{~m}$ a.s.l., which reduces the potentially confounding effect of altitude. Finally, the sites were within a small area of approximately $1.82 \mathrm{~km}^{2}$ (distance among sites between less than a hundred meters at confluences and $3.13 \mathrm{~km}$ ).

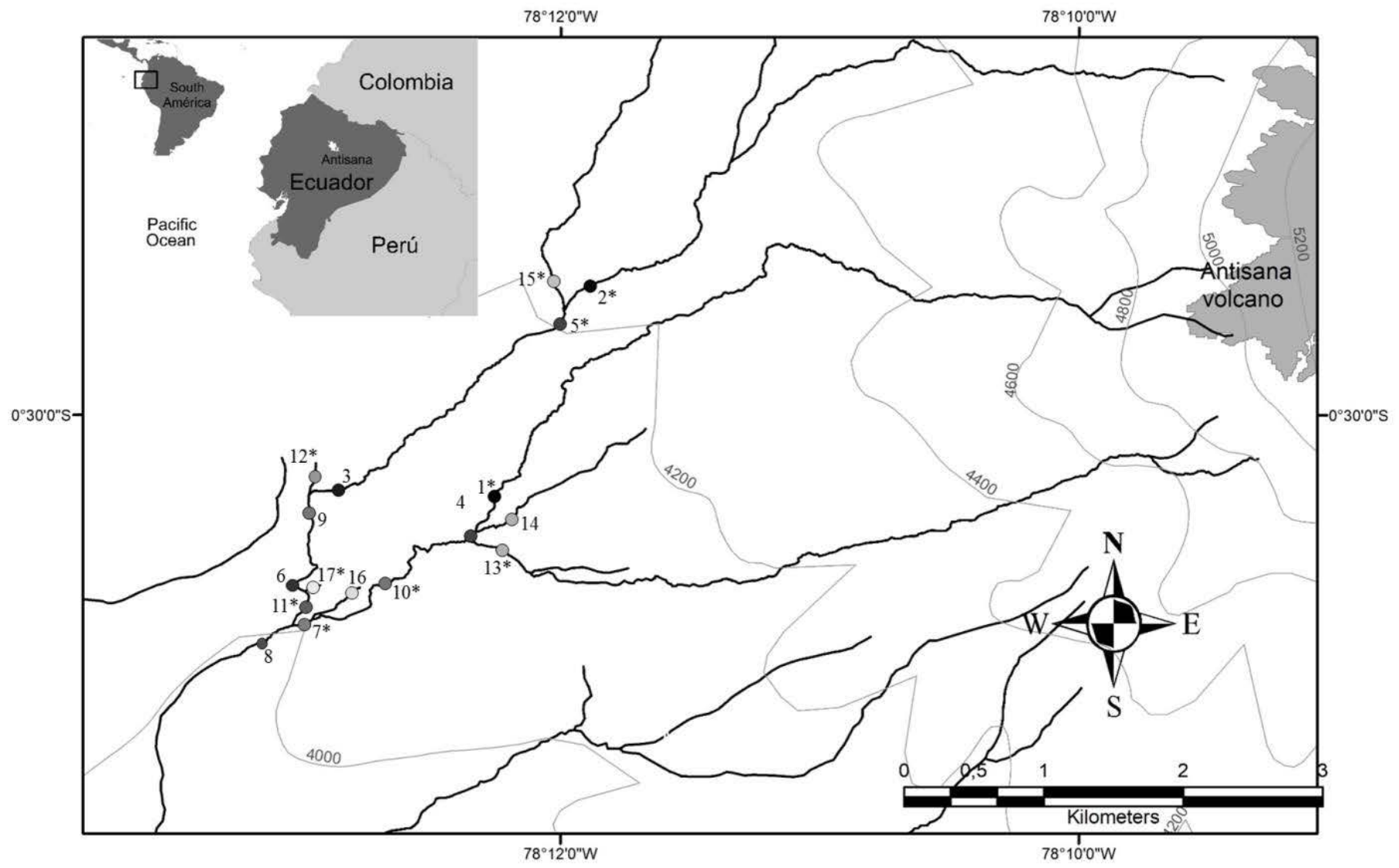

Figure 1. Location of study sites at the western foothills of the snowcapped Antisana volcano. The site's gray scale represents the glaciality index (GI), the darker the color, the higher the GI. * Indicates the sites from where individuals were collected for gut content analysis. 

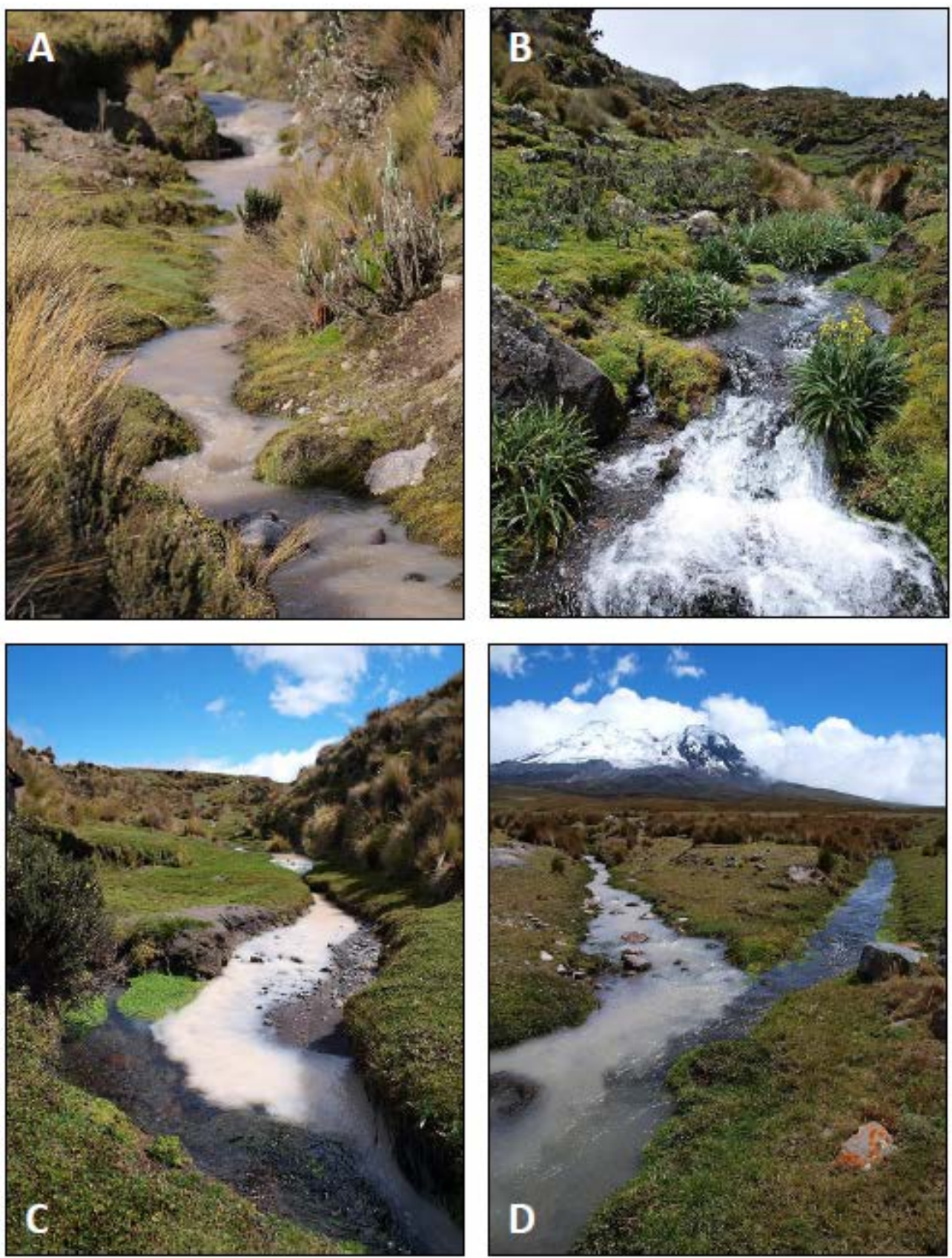

Figure 2. (A) Site 2, with one of the highest GI values. (B) The spring-fed site 17, with the lowest GI value of all. (C) Looking upstream at the junction between the spring-fed site 12 to the left and the primarily glacier-fed site 3 to the right. Site 9 would be just downstream from the picture. (D) Looking upstream at the junction between the primarily glacier-fed site 4 to the left and the primarily spring-fed site 13 to the right. Mt. Antisana is seen in the background. (Photos: Dean Jacobsen).

\subsection{Environmental Variables}

At every visit to each site, we did spot measurements of conductivity, $\mathrm{pH}$, temperature, and dissolved oxygen (both concentration and saturation) with WTW portable meters (WTW GmbH, Xilem Inc., Munich, Germany), and turbidity with a TN-100 EUTECH Turbidimeter. Additionally, we measured mean current velocity, discharge (using salt dilution gauging [42]), substrate stability (third part of the Pfankuch index [43]), and stream slope (see [36] for the methods). 
All measurements were performed in the morning before the daily glacial flow increase. We recorded water temperature and water pressure variations using Hobo water pressure loggers (Onset Computer Corp., Bourne, MA, USA) at each site. One logger was fixed on a rock at $4100 \mathrm{~m}$ a.s.l. to measure atmospheric pressure. All loggers were set to take measurements every $30 \mathrm{~min}$. As points of reference, water level and height between the stream bottom and the Hobo sensor were measured when the loggers were installed and when they were retrieved. To calculate stream depth, water pressure values were transformed into water level values by subtracting the atmospheric variations from the water pressure data [40].

\subsection{Glaciality Index}

A glaciality index has previously been developed for European alpine streams based on water temperature, conductivity, suspended solids, and the Pfankuch index [6]. Given the hydrological and environmental differences between alpine and Andean glacier-fed streams $[36,44]$, we developed a glaciality index slightly modified from those proposed by $[6,45]$. Our index was based on mean turbidity (a proxy of suspended sediments), conductivity, Pfankuch index for stream channel stability (only the channel bottom part [43]), and coefficient of variance $(\mathrm{CV})$ of temperature and depth. The methods for obtaining a glaciality index score (hereafter GI) for each of the 17 sites followed that of [45]; parameter values were scaled between 0 and 1 and processed in a non-centered principal component analysis (NPCA) where we used the first component values as GIs. Sites were ordered and named from one to 17 according to their glaciality index value, with site 1 having the highest GI score.

\subsection{Primary Food Sources}

We measured the amount of two food sources: (1) particulate organic matter (POM), comprising particles larger than $200 \mu \mathrm{m}$, mostly allochthonous organic matter, and (2) benthic periphytic algae (autochthonous resource). POM was obtained from five Surber samples $(20 \times 25 \mathrm{~cm}$; mesh size $200 \mu \mathrm{m})$ collected at each site (see below). After removal of macroinvertebrates, the material present in each Surber sample was filtered through a 200- $\mu \mathrm{m}$ sieve, dried at $80^{\circ} \mathrm{C}$ for $24 \mathrm{~h}$, weighed, and the mass loss upon combustion at $550{ }^{\circ} \mathrm{C}$ was taken as the amount of ash-free dry mass of POM $>200 \mu \mathrm{m}$ in the sample.

Chlorophyll a (Chl. a) concentration was calculated as a measure of benthic algal biomass. At each site, we randomly collected 15 pebbles (avoiding those with filamentous algae). Pebbles were placed in five containers (three in each) with $96 \%$ ethanol, and left for 1-3 days in the dark until further processing in the laboratory. Later, the containers were given a 10-min ultrasonic bath to increase extraction efficiency. After settlement for a few hours, a sample was transferred to a spectrophotometer and absorption was measured at 665 and $750 \mathrm{~nm}$. The concentration of total Chl. a (including phaeopigments) was calculated following [37]. The stone surface area was estimated using the same formula proposed by [46].

\subsection{Benthic Macroinvertebrate Sampling}

Quantitative data on macroinvertebrate assemblages were obtained from five Surber samples collected at each site. In order to standardize records, samples were collected within a reach of approx. $20 \mathrm{~m}$ and from areas with medium water flow and a substratum composed of pebbles-cobbles. Samples were preserved in 75\% ethanol. Macroinvertebrates were identified and counted under a stereoscope OLYMPUS SZ-6145 to the highest taxonomic resolution possible using local and regional taxonomic reference literature [47]. 


\subsection{Functional Feeding Group Affiliation and Gut Content Analysis}

In order to enhance thee statistical reliability of quantitative multivariate analysis, we excluded non-abundant species (taxa with less than 50 individuals in total) from the analyses [48], and, thus, a total of 27 taxa (separating larvae and adults of Neoelmis) were analyzed. Studies on ecological structure and ecosystem processes in streams is limited by incomplete and erroneous classification of invertebrates to FFGs, in particular regarding less well studied alpine streams [35], and even more so when it comes to high-Andean streams [49]. Therefore, here, the assignment of macroinvertebrate taxa to specific FFGs was conducted in two ways. For the 15 taxa for which the literature $[11,47,48,50-53]$ provided detailed and consistent information on specialized feeding habits in accordance with our own experience, these were used as the FFG. For the remaining 12 taxa with scarce or inconsistent literature information and less specialized mouth parts, we analyzed the gut content, and estimated the proportion of different food types within the foregut (initial half of the digestive tract). Thus, gut content analysis was used as a proxy for FFG affiliation. Five categories of food types were identified: (i) filamentous algae; (ii) diatoms; (iii) coarse detritus ( $>200 \mu \mathrm{m}$ ); (iv) fine detritus $(<200 \mu \mathrm{m})$; and (v) animal tissue (similar to [54]). The 12 taxa analyzed were Hyalella sp. (Hyalellidae, Amphipoda), Claudioperla sp. (Gripopterygidae, Plecoptera), Andesiops sp. (Baetidae, Ephemeroptera), Anomalocosmoecus sp. (Limnephilidae, Trichoptera), Mortoniella sp. (Glossosomatidae, Trichoptera), Orchrotrichia sp., Neotrichia sp. (Hydroptilidae, Trichoptera), Cyphon sp. (Scirtidae, Coleoptera), Neoelmis sp. larvae, Neoelmis sp. adult (Elmidae, Coleoptera), Blepharicera sp. (Blephariceridae, Diptera), and Molophilus sp. (Limoniidae, Diptera). Gut content analysis was performed on 10 randomly chosen individuals obtained from Surber samples from ten sites (one individual per site) covering the whole GI gradient (from site 1 to 17). Based on either referential literature information or gut content analysis, the following nine specific FFGs were defined following the notion presented in [51,55], and the clustering method of proportional food resource used by [48]: predators/scrapers, predators/collectors, predators, scrapers, shredders/scrapers, shredders, shredders/collectors, collectors/scrapers, collectors (see more details under data treatment).

\subsection{Detritus Decomposition}

Decomposition of the dominant riparian vegetation, common páramo grass Calamagrostis intermedia (J. Presl.) Steud., was measured as mass loss of $5.0 \mathrm{~g}$ DW of abscised leaf blades representative of those that naturally enter streams. Leaf blades were placed in litterbags $(15 \times 10 \mathrm{~cm})$ of two different mesh sizes $(0.3$ and $5 \mathrm{~mm})$. The fine-mesh bags excluded macroinvertebrates, while coarse-mesh bags did not. Initially six, and later ten, replicate bags of each type were installed in each stream. The exposure started at the beginning of March 2014 and lasted for 92 days, except for the five sites $(2,5,6,7,15)$, where bags were left for 35 days (due to logistic constraints). After retrieval, the grass material was rinsed to remove fine particulate matter and invertebrates [56]. The remaining plant material was dried $\left(48 \mathrm{~h}\right.$ at $\left.50^{\circ} \mathrm{C}\right)$, weighed, ashed $\left(4 \mathrm{~h}\right.$ at $\left.550{ }^{\circ} \mathrm{C}\right)$, and weighed again to calculate ash-free dry mass (AFDM). AFDM was used to calculate daily decomposition rate $(\mathrm{k})$ for each litterbag using the well-established negative exponential decay model [57], which reflects the most commonly observed functional response for leaf decomposition in streams [58,59]. To account for the effect of temperature on decomposition [60], we also calculated the decomposition rate per degree day. For this, we replaced time $(t)$ with the sum of mean daily temperatures (above $0{ }^{\circ} \mathrm{C}$ ) accumulated until retrieval. We subtracted decomposition rates in fine mesh bags $\left(\mathrm{k}_{\mathrm{FM}}\right)$ from those in coarse mesh bags $\left(\mathrm{k}_{\mathrm{CM}}\right)$ to represent macroinvertebrate activity and physical abrasion $\left(\mathrm{k}_{\mathrm{CM}}-\mathrm{k}_{\mathrm{FM}}\right)$. 


\subsection{Data Treatment}

We used the proportional food resource data from the gut content analysis and referential literature data for each taxon in a common paired group cluster analysis (PGCA) on all 27 taxa with Euclidean similarity measures to define the nine specific FFGs and to determine the taxa belonging to each of them, following the rationale of [48]. Densities of each of the nine FFGs at each site were then calculated from taxon abundances in the Surber samples. An ordination triplot from a canonical correspondence analysis (CCA) of the 17 sites based on FFG densities and with POM, Chl. A, and GI included as environmental variables (all log-transformed) was performed as a direct gradient analysis. All the above analyses were conducted using the PAleontological STatistics (PAST) software [61].

Differences in detritus decomposition between bag types were tested by paired $t$ tests, after having checked for normality by Shapiro-Wilk and Kolmogorov-Smirnov tests. Relationships between POM, Chl. a, macroinvertebrate density, taxon richness, number of FFGs, density of individual FFGs, and decomposition rates as dependent variables and GI as the independent variable were investigated by comparing best fit simple linear, exponential, or quadratic regression models. Bonferroni correction for multiple comparisons was not applied when evaluating the significance of P-values. T-tests and regressions were undertaken using SPSS software version 27.

To further search for relationships between detritus decomposition rates and site characteristics (both environmental and biological) as independent factors, we used generalized additive models (GAMs) in the R package MGCV. First, we tested the effect of all factors independently upon $\mathrm{k}_{\mathrm{CM}}, \mathrm{k}_{\mathrm{FM}}$, and $\mathrm{k}_{\mathrm{CM}}-\mathrm{k}_{\mathrm{FM}}$. Then, we built models including all individual factors that proved significant in the first round, and selected the best models according to the lowest AIC. Due to the relatively low number of sites, we did not include interaction effects in the models.

\section{Results}

\subsection{Glaciality Index, Environmental Variables, and Food Sources}

Environmental characteristics for the 17 study sites are provided in SI 1 and SI 2 . The first two axes of the NPCA used to assign the glaciality index to our 17 sites accounted for $82 \%$ and $15 \%$ of the total variability, respectively (SI 3). Of the five chosen variables, turbidity and conductivity were those that contributed most to defining this gradient, the temperature CV and Pfankuch index contributed less, while that of depth CV was lower than $1 \%$ for both axes. The first axis values provided a quite evenly distributed gradient in GI, from 0.328 and 0.297 at the two purely glacier-fed sites 1 and 2 to 0.129 and 0.160 at the two spring-fed sites 17 and 16 (SI 1).

POM and periphyton pools varied greatly among stream sites. POM was highest at site $3\left(28.5 \mathrm{~g} \mathrm{AFDW} \mathrm{m}^{-2}\right)$ and lowest at site $10\left(2.5 \mathrm{~g} \mathrm{AFDW} \mathrm{m}^{-2}\right)$, but unrelated to GI (Figure 3A). Chlorophyll a concentration varied from $187.7 \mathrm{mg} \mathrm{m}^{-2}$ at site 6 to $16.2 \mathrm{mg} \mathrm{m}^{-2}$ at site 4 . A weak (non-significant) negative exponential relationship between Chl. a and GI may be recognized $\left(R^{2}=0.16, p=0.598\right)$, and if the $188 \mathrm{mg} \mathrm{Chl}$. a outlier is omitted, the relationship becomes highly significant $\left(R^{2}=0.41, p=0.008\right)$ (Figure 3B). 


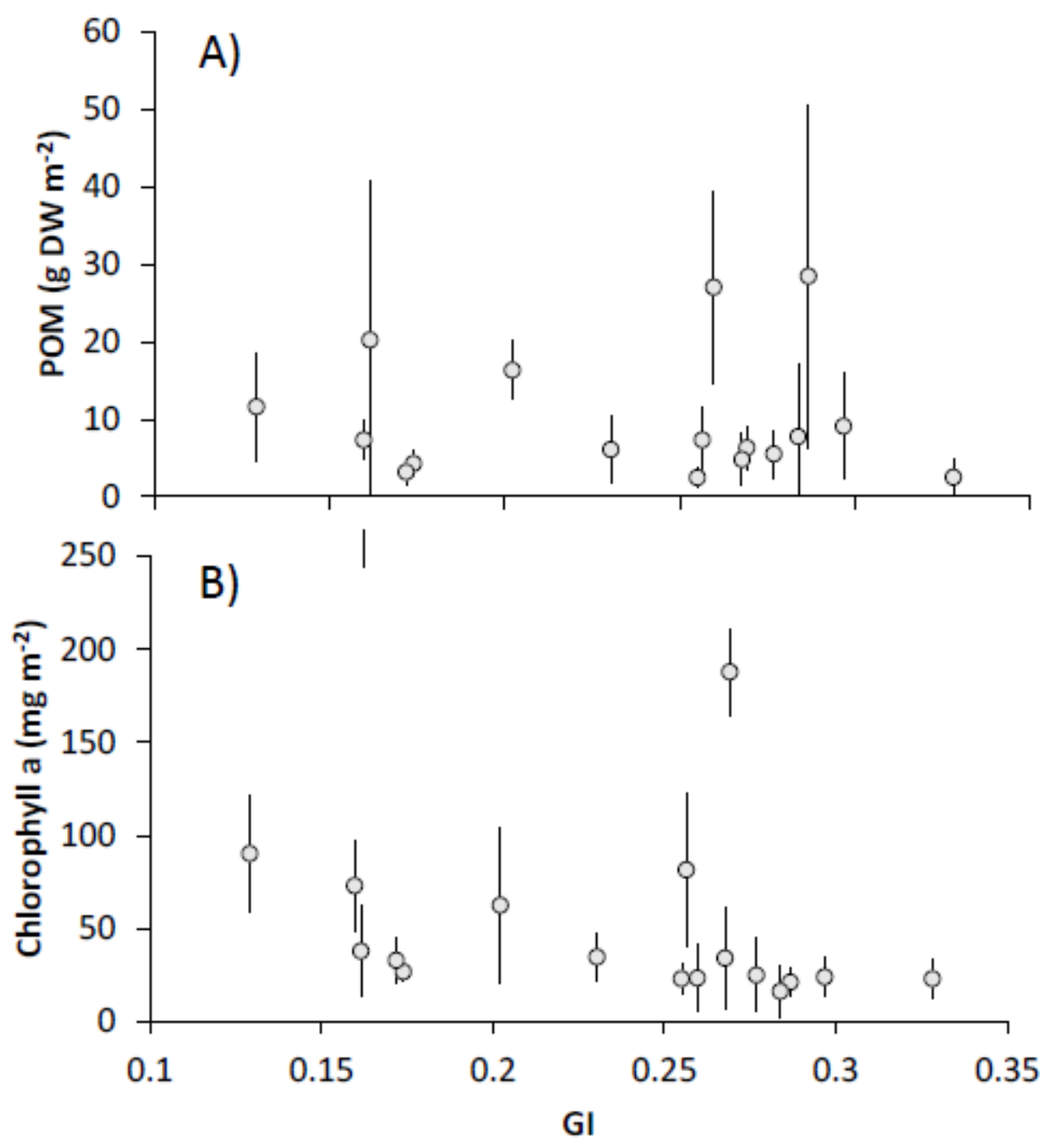

Figure 3. Average quantities of (A) particulate organic matter (POM) and (B) chlorophyll $a$ (Chl. $a$ ) along the gradient of glaciality index (GI). Error bars represent SD.

\subsection{Functional Feeding Group Affiliation and Distribution Patterns}

We sampled a total of 123,040 macroinvertebrate individuals. The density varied between 1131 (site 1) and 17,529 ind. $\mathrm{m}^{-2}$ (site 14). In total, 27 taxa were collected, varying between 13 (site 1) and 24 taxa (site 7) per site (SI 4). Density of macroinvertebrates showed a negative exponential $\left(R^{2}=0.38, p=0.009\right)$ and taxon richness $\left(R^{2}=0.39, p=0.033\right)$ a hump-shaped, quadratic relationship with increasing GI (Figure 4A,B).

The most abundant food items identified in the gut content analyses were coarse detritus (10-52\%, mean $25 \%$ ) and fine detritus ( $8-47 \%$, mean $18 \%$ ) while filamentous algae (9-37\%, mean $14 \%$ ) and diatoms (5-42\%, mean $13 \%$ ) were less ingested. Animal parts were rarely found in guts $(0-9 \%$, mean $0.8 \%$ ) (SI 5$)$. Considerable amounts of fine glacial rock fragments were also observed in the guts.

From diet composition based on gut content and literature classification, the result of the PGCA clustered the 27 taxa into nine specific FFGs: four specialist feeding groups (predators, scrapers, shredders, and collectors) and five groups with more generalist feeding traits (predators/scrapers, predators/collectors, collectors/scrapers, shredders/scrapers, and shredders/collectors). Specialist predators included five taxa (all from literature classification), specialist shredders and scrapers four taxa each, and collectors (gatherers and filterers) three taxa. All generalist groups contained two taxa each. The number of FFGs per site ranged from six to nine and were related to GI in a hump-shaped, 
quadratic way $\left(R^{2}=0.51, p=0.007\right)$, even though the hump-shaped pattern only arises due to the site with the highest GI (Figure $4 \mathrm{C}$ ).
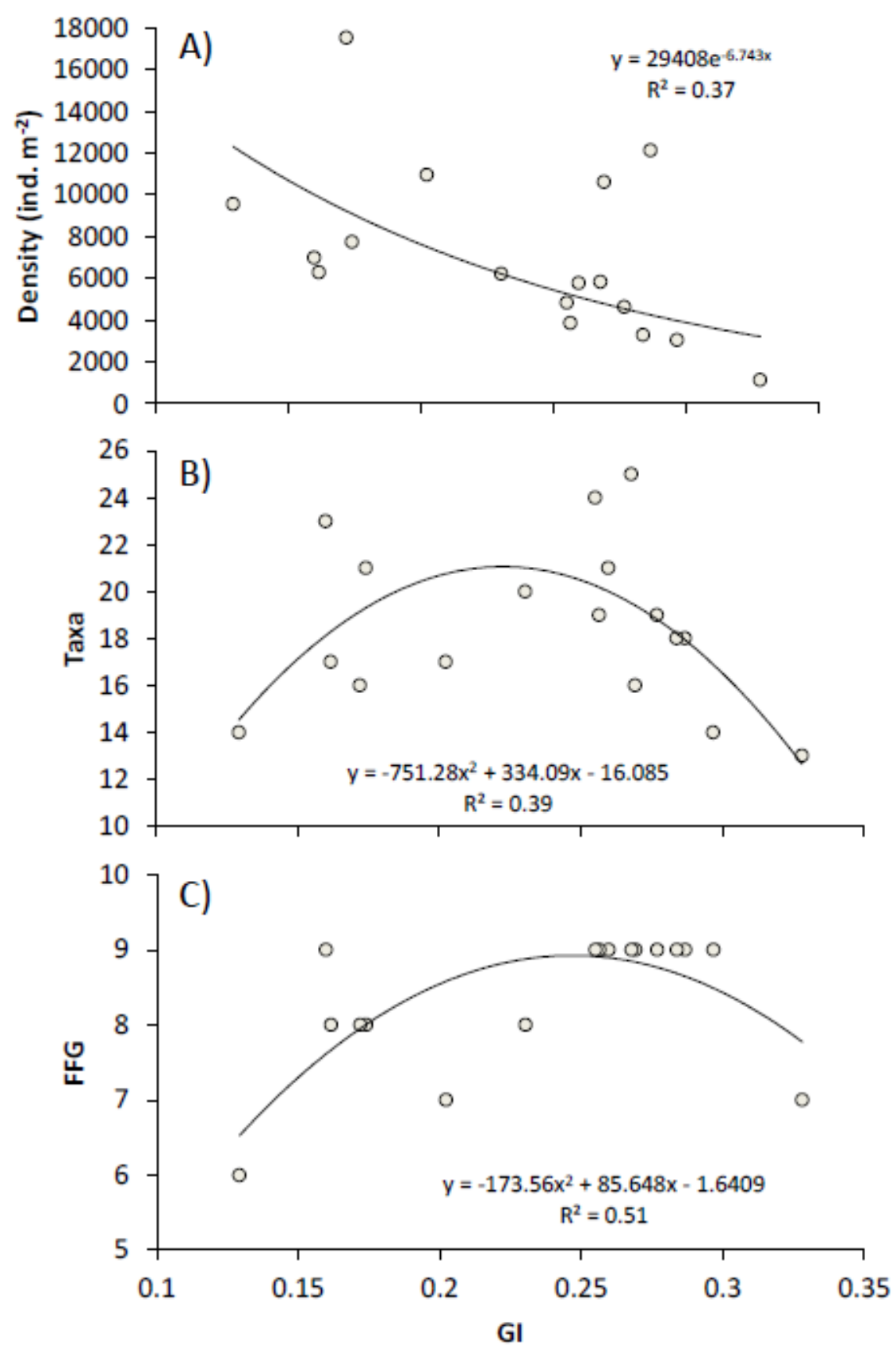

Figure 4. Density (A), number of taxa (B), and number of FFGs (C) of benthic macroinvertebrates along the gradient of glaciality index (GI). Results of exponential (density) and quadratic regressions (taxon richness and number of FFGs) are shown.

Abundances from Surber samples were grouped according to the nine FFGs (SI 4). Collectors/scrapers (mainly Chironomidae) were the most abundant, constituting $29.2 \%$ of all individuals). Shredders/scrapers constituted $26.4 \%$ of individuals, and these were mainly Hyalella sp. (Hyalellidae). Scrapers accounted for $25.1 \%$ of individuals, mainly Andesiops sp. (Baetidae). Finally, we observed $7.4 \%$ shredders, and these were primarily Anomalocosmoecus sp. (Limnephilidae).

The CCA triplot based on FFG densities showed a GI gradient that clearly followed the first axis (Figure 5). Shredders, shredders/scrapers, scrapers, and predators were 
associated with high Chl. a and low GI. Most generalist feeding groups such as predator/collectors, shredder/collectors, and predator/scrapers were more closely related to high GI. In addition, predator/collectors and shredder/collectors were associated with high POM values. The regression analyses showed that the densities of predators $\left(R^{2}=0.459, p=0.003\right)$ and shredders $\left(R^{2}=0.342, p=0.014\right)$ were linearly and negatively related to GI, while predator/collectors $\left(\mathrm{R}^{2}=0.241, p=0.045\right)$ and collector/scrapers $\left(R^{2}=0.353, p=0.012\right)$ were linearly and positively related to Chl. a. No FFG related significantly to POM.

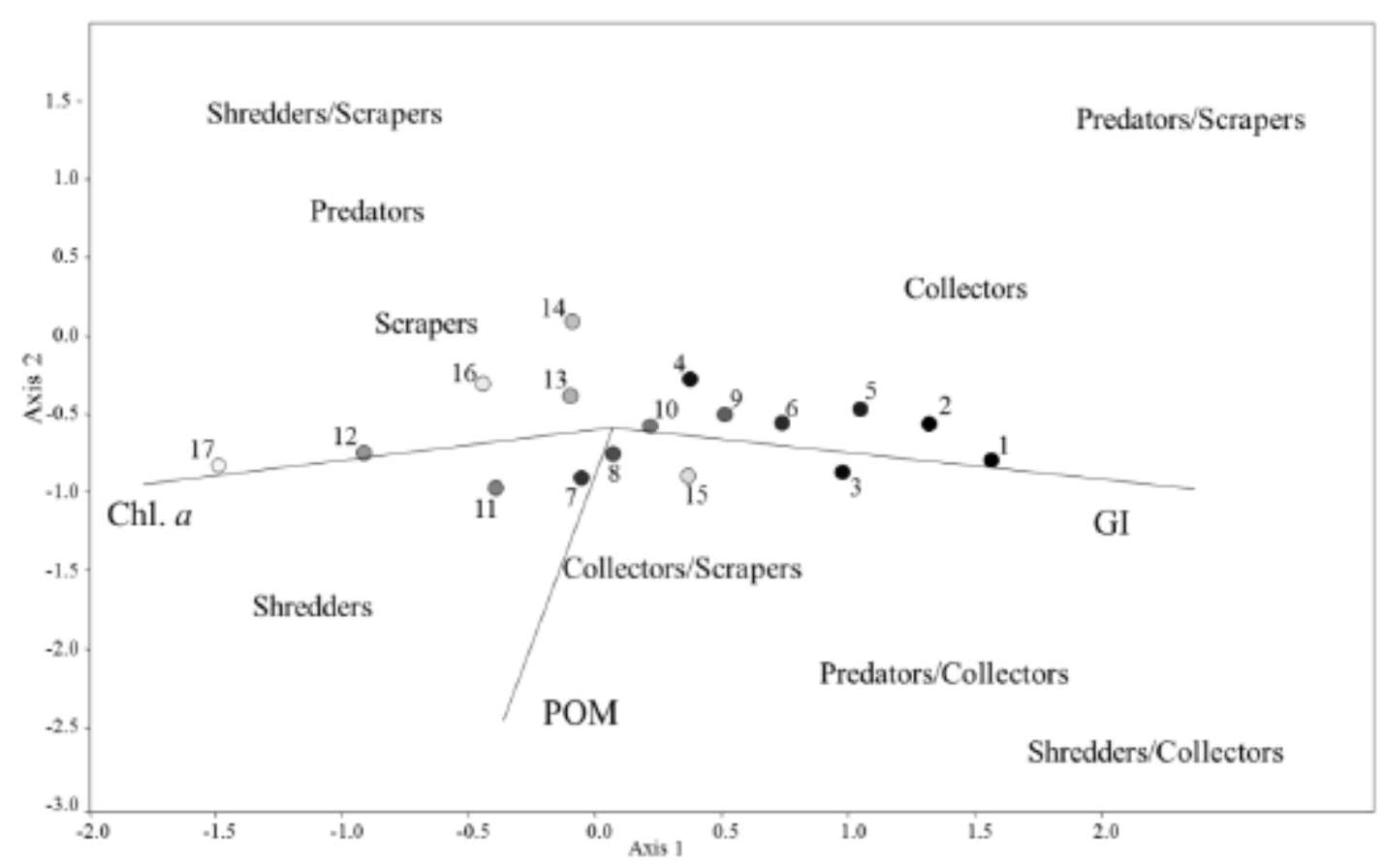

Figure 5. Canonical correspondence analysis (CCA) biplot on functional feeding groups, and with the environmental variables (vectors) particulate organic matter (POM), chlorophyll $a$ (Chl. a), and the glaciality index (GI) plotted as correlations with site scores (scaling type 1).

\subsection{Detritus Decomposition}

Average mass loss of Calamagrostis leaf packs ranged from six to $55 \%$ and from six to $44 \%$ in coarse and fine mesh bags, respectively. Decomposition rates ( $\mathrm{k}$ values) differed greatly among sites, but were always higher in coarse than in fine mesh bags $(p<0.001$; paired $t$-test). There was also a highly significant linear relationship between decomposition rates in coarse and fine mesh bags $\left(\mathrm{R}^{2}=0.84, p<0.001\right.$; linear regression). There were no differences in decomposition rates between bags exposed for 35 days and those exposed for 92 days, neither for coarse ( $p=0.77$; $t$-test) nor for fine mesh bags $(p=0.98)$. Daily decomposition rates for coarse mesh bags $\left(\mathrm{k}_{\mathrm{CM}}\right)$ were $0.0019-0.0088$ (median 0.0048 day $^{-1}$ ) and for fine mesh bags $\left(\mathrm{k}_{\mathrm{FM}}\right)$ 0.0010-0.0065 (median 0.0028 day $^{-1}$ ) (SI 6). Although regressions of $\mathrm{k}_{\mathrm{CM}}$ and $\mathrm{k}_{\mathrm{FM}}$ against GI were non-significant, we found that quadratic models best explained the relationship, showing the highest decomposition rates at medium values of GI, while this pattern was much less evident for $\mathrm{k}_{\mathrm{CM}}-\mathrm{k}_{\mathrm{FM}}$ (i.e., shredder activity plus physical abrasion) (Figure 6). Likewise, the GAMs found no significant relationship between any of the decomposition rates and GI (SI 7). Rates based on degree-days (dd) varied between 0.00025 and 0.00104 for $\mathrm{k}_{\mathrm{CM}}$ (median $0.00054 \mathrm{dd}^{-1}$ ) and from 0.00014 to 0.00082 for $\mathrm{k}_{\mathrm{FM}}$ (median $0.00035 \mathrm{dd}^{-1}$ ). Decomposition rates calculated in $\mathrm{dd}^{-1}$ showed all the same patterns as those described above for rates day ${ }^{-1}$, except that $R^{2}$ values for regressions against GI were slightly lower using dd (not shown). 


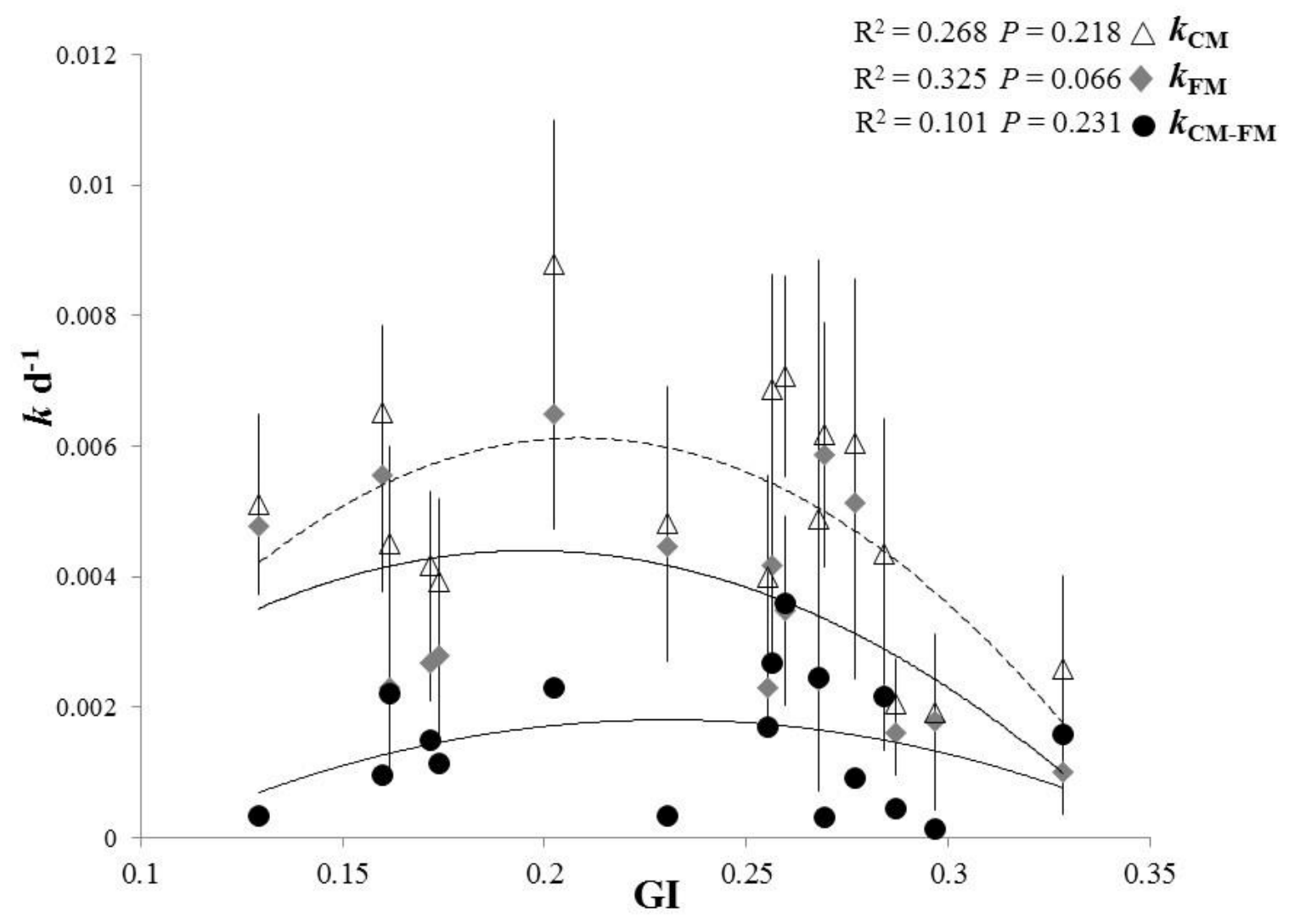

Figure 6. Decomposition rates of Calamagrostis in coarse mesh bags $\left(\mathrm{k}_{\mathrm{CM}}\right.$, dashed line), fine mesh bags $\left(\mathrm{k}_{\mathrm{FM}}\right)$, and their difference $\left(\mathrm{k}_{\mathrm{CM}}-\mathrm{k}_{\mathrm{FM}}\right)$ along the glaciality index $(\mathrm{GI})$. Results of the quadratic regressions are shown.

Results from the GAMs indicated significant effects of some of the individual site characteristics on decomposition rates. Rates in coarse mesh bags $\left(\mathrm{k}_{\mathrm{CM}}\right)$, when tested against variables individually, were related to predator/collector abundance, temperature CV (both negative), Pfankuch index, and Chl. a (both hump-shaped) (all $p<0.05$ ), while in the model including these four factors only predators/collectors, temperature CV (U-shaped) and Pfankuch index (hump-shaped) were significant $(p<0.05)$ (SI 7). Fine mesh bag rates $\left(\mathrm{k}_{\mathrm{FM}}\right)$, when tested against factors individually, were related to temperature $\mathrm{CV}$, turbidity (both negative), Pfankuch index (hump-shaped), and Chl. a (saturation) (all $p<0.05$ ), while in the model including these four factors, only temperature CV (negative) and Chl. a (positive) were significant $(p<0.05)$ (SI 7). The $\mathrm{k}_{\mathrm{CM}}-\mathrm{k}_{\mathrm{FM}}$ difference was only related negatively to scraper abundance (both $p<0.05$ ) (SI 7).

\section{Discussion}

\subsection{Glaciality Index, Environmental Variables, and Food Sources}

In Swiss alpine streams, maximum temperature, conductivity, and substrate stability were found to be important for placing sites along a gradient of glacier influence [6]. In contrast, in our study on the Ecuadorian streams, turbidity contributed the most to our GI, followed by conductivity and, to a much lesser extent, temperature variation. This difference could be because our slightly modified GI was applied not only to glacier-fed streams, but to spring-fed and superficial drainage-fed streams, and because larger glaciers (and rivers) were included in the study by [6].

Levels of benthic algae biomasses (measured as Chl. a concentration) were high in our sites compared to summer levels reported from European alpine streams, but were more comparable to those during low flow conditions during early spring and autumn $[15,62,63]$. In accordance with [15], we found a slight decrease in benthic Chl. a toward higher levels of glacial influence (Figure 3). Another study from the same Andean glacier-fed streams as 
ours, but at higher altitudes and closer to the glaciers, found considerably lower benthic algal biomass, and showed that the variation in biomass was mainly related to water temperature, concentration of suspended solids (turbidity), and Pfankuch stability [37].

Coarse particulate organic matter inputs are usually low or lacking at high latitude, alpine streams, especially in glacier-fed ones with sparse or no riparian vegetation $[17,64]$. Additionally, detritus is retained for shorter periods in turbulent and hydrologically unstable streams $[65,66]$. We found that POM pools were high compared to streams in the Alps [17,62]. Our POM pools were comparable to those reported by Kuhn et al. [37], and virtually constant along the GI gradient (Figure 3). The dense páramo vegetation of grass and shrubs in equatorial highlands probably provides considerable input of allochthonous POM [2]. It is important to note that all 17 stream sites were located roughly at the same altitude, with no systematic difference in riparian vegetation along the GI gradient. In addition, as opposed to temperate regions, in the tropics, allochthonous organic matter input occurs year round, and not as short seasonal pulses [67]. However, pools of POM not only depend on riparian allochthonous input, but also on autochthonous production (aquatic macrophytes), retention, and decomposition rates. We did not determine the origin of POM in the Surber samples, and part of the POM could stem from submerged and emergent aquatic macrophyte vegetation that is common in these streams including those with glacial influence. Finally, decomposition rates (discussed below) were relatively low.

\subsection{Functional Feeding Group Affiliation and Distribution Patterns}

Invertebrate density was inversely related to GI while taxon richness, and to a lesser degree FFG richness, showed a hump-shaped relationship. FFG richness was less affected by GI, since the fewer taxa present at higher GI represented more feeding guilds. The hump-shaped pattern in taxon richness has been found in previous studies from the same region $[38,68]$. Functional diversity of aquatic macroinvertebrates varies with land cover type in alpine streams [69], and decreases with increasing glacier cover in Arctic-temperate catchment [9]. However, in this equatorial alpine catchment, overall functional diversity seems to mirror the humped-shaped taxon richness versus GI pattern [39], here shown specifically by the number of FFGs. Most generalist feeding groups such as collectors, predators/collectors, shredders/collectors, and predators/scrapers were more closely related to the harsher environment at high GI levels. This high degree of feeding generalism or omnivory in glacier-fed streams seems to be in accordance with studies from the European Alps [10-12,35].

Shredders showed a significantly negative relationship with the GI, in accordance with the findings in [39]. The distribution of shredders toward streams with lower GI does not appear to be driven by POM, because shredder abundance did not correlate to POM, which, in turn, showed no significant pattern along the GI gradient (Figure 3). Thus, species contributing to shredding (primarily Hyalella sp. and Anomalocosmoecus sp.) seem to be particularly limited by the environmental harshness at high GI rather than food sources.

\subsection{Detritus Decomposition}

Our decomposition rates for both coarse mesh (median $0.0048 \mathrm{~d}^{-1}$ ), and in particular for fine mesh bags (median $0.0028 \mathrm{~d}^{-1}$ ), were slightly lower than those reported by [56] for Calamagrostis in nearby, non-glacial, and slightly lower lying páramo streams $\left(\mathrm{k}_{\mathrm{CM}}\right.$ median $0.0057 ; \mathrm{k}_{\mathrm{FM}}$ median $0.0048 \mathrm{~d}^{-1}$ ). These authors found that decomposition rates were lower in streams with low taxon richness and abundance of shredders (primarily Hyalella sp., Anomalocosmoecus sp. and Nectopsyche sp.). It is well established that decomposition rates vary greatly among different species of leaf litter [70], so direct comparison with other studies using other leaf species is problematic. Nevertheless, compared to the decomposition of Alnus sp. leaves (which is a relatively quickly decomposed species) in Swiss alpine streams $\left(\mathrm{k}=0.0029-0.0305 \mathrm{~d}^{-1}\right.$ [19]), our decomposition rates were also low. The lowest decomposition rates of Alnus sp. leaves occurred immediately below glaciers, where microbial action was the main contributor. Decomposition rates of Alnus sp. in coarse 
mesh bags were considerably higher in glacier lake outlets, where the glacial influence is moderated by a less harsh environment (in particular higher mean temperatures), thus allowing higher densities of shredders (the trichopteran Acrophylax zerberus) [19]. Our rates for Calamagrostis sp. seem to be quite comparable to those found in Swiss Alpine streams for Larix sp. needles (which is a relatively slowly decomposed species) with $\mathrm{k}$ ranging $0.0017-0.0055 \mathrm{~d}^{-1}$ [16]. Again, the decomposition of the Larix sp. needles was highest in a spring brook due to abundant nemourid stonefly shredders compared to a pro-glacial and a glacial lake outlet stream. Overall, the relatively high average temperature of the equatorial alpine streams $\left(7-10^{\circ} \mathrm{C}\right)$ compared to e.g., European Alpine streams apparently does not raise decomposition rates accordingly.

Our study showed a non-significant, although somewhat intriguing hump-shaped relationship between decomposition rates for both fine and coarse mesh bags and GI values (Figure 6). The GAM analyses revealed that several of the environmental variables included in the GI had significant effects on decomposition rates, but that this humped-shape of both $\mathrm{k}_{\mathrm{CM}}$ and $\mathrm{k}_{\mathrm{FM}}$ seemed to be related mainly to the Pfankuch index (i.e., the physical stability of the stream bed). In addition, the temperature $\mathrm{CV}$ had a consistently negative effect on both $\mathrm{k}_{\mathrm{CM}}$ and $\mathrm{k}_{\mathrm{FM}}$, both tested individually and in combined models. However, these relationships are hard to explain. The GAMs found no effect of shredders on decomposition rates, instead, effects were found for predators/collectors $\left(\mathrm{k}_{\mathrm{CM}}\right)$ and scrapers $\left(\mathrm{k}_{\mathrm{CM}}-\mathrm{k}_{\mathrm{FM}}\right)$. These effects are hard to explain, but we obviously cannot dismiss that some taxa have been misplaced regarding FFG.

As expected, $\mathrm{k}_{\mathrm{CM}}$ was generally higher than $\mathrm{k}_{\mathrm{FM}}$ rates, but overall, the two quadratic regressions followed each other closely, so the absolute difference between the two treatments varied little across the entire GI gradient (Figure 6). The difference in decomposition rates between fine and coarse mesh bags is usually attributed to shredding by macroinvertebrates and physical abrasion and fragmentation [59]. Thus, the effect of macroinvertebrate shredders (mainly Hyalella sp. and Anomalocosmoecus sp.) appeared to be minor compared to the microbially mediated decomposition, which in fact only decreased very slightly toward low GI values, but more clearly toward high GI. Surprisingly, while shredder abundance was unrelated to POM quantities, they showed a very clear decreasing abundance, and virtually disappeared at high GI levels (Figure 5). As neither $\mathrm{k}_{\mathrm{CM}}$ nor $\mathrm{k}_{\mathrm{CM}}-\mathrm{k}_{\mathrm{FM}}$ rates were related to the abundance of shredders, the nearly constant $\mathrm{k}_{\mathrm{CM}}-\mathrm{k}_{\mathrm{FM}}$ difference and the increasing $\mathrm{k}_{\mathrm{CM}}: \mathrm{k}_{\mathrm{FM}}$ ratio toward high GI levels (data not shown) are probably due to increased physical abrasion and fragmentation at high GI, as suggested by [16] and [18], while at low GI levels, shredders contribute relatively more and physical abrasion relatively less to decomposition.

\section{Conclusions}

Our study showed that (1) food resources such as POM and benthic periphyton in an Ecuatorial high páramo stream network were not related to glacial meltwater influence (within the lower end of the gradient, as studied here); (2) that generalist FFGs dominate at high levels of glacial influence; and (3) that decomposition rate of detritus appeared to be hump-shaped related to glacial influence, and our results suggest that tropical glacier loss will not change the dominant microbial role in detritus decomposition, but that the physical abrasion might be partially replaced by biological processes such as shredder action with reduced glacial influence. 
Supplementary Materials: The following are available online at https://www.mdpi.com/article/10 $.3390 / \mathrm{w} 13223303 / \mathrm{s} 1$.

Author Contributions: Conceptualization, P.A., V.C.-P., O.D. and D.J.; Methodology, O.D. and P.A.; Software, P.A., D.J. and S.C.-F.; Validation, P.A., D.J. and S.C.-F.; Formal Analysis, P.A., D.J. and S.C.-F.; Investigation, P.A; Resources, P.A., V.C.-P., O.D. and D.J.; Data Curation, P.A., R.E. and V.C.-P.; Writing-Original Draft Preparation, P.A.; Writing—Review \& Editing, D.J.; Visualization, P.A. and D.J; Supervision, O.D. and V.C.-P.; Project Administration, O.D., V.C.-P. and R.E.; Funding Acquisition, O.D. and V.C.-P. All authors have read and agreed to the published version of the manuscript.

Funding: The work was financially supported by PUCE, Ecofondo (Project 034-ECO8-inv1).

Institutional Review Board Statement: Not applicable.

Informed Consent Statement: Not applicable.

Data Availability Statement: All data are available in the Supplementary Materials and upon request from P.A. and D.J.

Acknowledgments: We greatly appreciate Gabriela Toscano and Tjite DeVries for lending us equipment and for their insightful comments at the beginning of this study. Many people participated in the fieldwork and data collection; we acknowledge their effort and wish to thank them all.

Conflicts of Interest: The authors declare no conflict of interest.

\section{References}

1. Jacobsen, D.; Dangles, O. Environmental harshness and global richness patterns in glacier-fed streams. Glob. Ecol. Biogeogr. 2012, 21, 647-656. [CrossRef]

2. Jacobsen, D.; Dangles, O. Ecology of High Altitude Waters; Oxford University Press: Oxford, UK, $2017 ;$ p. 304.

3. Castella, E.; Adalsteinsson, H.; Brittain, J.E.; Gislason, G.M.; Lehmann, A.; Lencioni, V.; Lods-Crozet, B.; Maiolini, B.; Milner, A.M.; Olafsson, J.O.; et al. Macrobenthic invertebrate richness and composition along a latitudinal gradient of European glacier-fed streams. Freshw. Biol. 2001, 46, 1811-1831. [CrossRef]

4. Füreder, L. Melting biodiversity. Nat. Clim. Chang. 2012, 2, 318-319. [CrossRef]

5. Scotti, A.; Tappeiner, U.; Bottarin, R. Stream benthic macroinvertebrates abundances over a 6-Year monitoring period of an Italian glacier-Fed stream. Biodivers. Data J. 2019, 7, e33576. [CrossRef]

6. Ilg, C.; Castella, E. Patterns of macroinvertebrate traits along three glacial stream continuums. Freshw. Biol. 2006, 51, 840-853. [CrossRef]

7. Füreder, L. Life at the Edge: Habitat Condition and Bottom Fauna of Alpine Running Waters. Intern. Rev. Hydrobiol. 2007, 92, 491-513. [CrossRef]

8. Milner, A.M.; Brown, L.E.; Hannah, D.M. Hydroecological response of river systems to shrinking glaciers. Hydrobiol. Proc. 2009, 23, 62-77. [CrossRef]

9. Brown, L.E.; Khamis, K.; Wilkes, M.; Blaen, P.; Brittain, J.E.; Carrivick, J.L.; Fell, S.; Friberg, N.; Füreder, L.; Gislason, G.M.; et al. Functional diversity and community assembly of river invertebrates show globally consistent responses to decreasing glacier cover. Nat. Ecol. Evol. 2018, 2, 325-333.

10. Füreder, L.; Welter, C.; Jackson, J.K. Dietary and stable isotope $(\delta 13 \mathrm{C}, \delta 15 \mathrm{~N})$ analyses in alpine stream insects. Intern. Rev. Hydrobiol. 2003, 88, 314-331. [CrossRef]

11. Clitherow, L.R.; Carrivick, J.L.; Brown, L.E. Food Web Structure in a Harsh Glacier-Fed River. PLoS ONE 2013,8 , e60899.

12. di Cugno, N.; Robinson, C.T. Trophic structure of macroinvertebrates in alpine non-glacial streams. Fundam. Appl. Limnol. 2017, 190, 319-330. [CrossRef]

13. Niedrist, G.H.; Füreder, L. When the going gets tough, the tough get going: The enigma of survival strategies in harsh glacial stream environments. Freshw. Biol. 2018, 63, 1260-1272. [CrossRef]

14. Zah, R.; Burgherr, P.; Bernasconi, S.M.; Uehlinger, U. Stable isotope analysis of macroinvertebrates and their food sources in a glacier stream. Freshw. Biol. 2001, 46, 871-882. [CrossRef]

15. Uehlinger, U.; Robinson, C.T.; Hieber, M.; Zah, R. The physico-Chemical habitat template for periphyton in alpine glacial streams under a changing climate. Hydrobiologia 2010, 657, 107-121. [CrossRef]

16. Robinson, C.T.; Gessner, M.O.; Callies, K.A.; Jolidon, C.; Ward, J.V. Larch needle breakdown in contrasting streams of an alpine glacial floodplain. J. N. Am. Benthol. Soc. 2000, 19, 250-262. [CrossRef]

17. Zah, R.; Uehlinger, U. Particulate organic matter inputs to a glacial stream ecosystem in the Swiss Alps. Freshw. Biol. 2001, 46, 1597-1608. [CrossRef]

18. Robinson, C.T.; Jolidon, C. Leaf breakdown and the ecosystem functioning of alpine stream. J. N. Am. Benthol. Soc. 2005, 24, 495-507. [CrossRef] 
19. Robinson, C.T.; Gessner, M.O.; Ward, J.V. Leaf breakdown and associated macroinvertebrates in alpine glacial streams. Freshw. Biol. 1998, 40, 215-228. [CrossRef]

20. Li, Y.J.; Ding, Y.J.; Shangguan, D.H.; Wang, R.J. Regional differences in global glacier retreat from 1980 to 2015. Adv. Clim. Chang. Res. 2019, 10, 203-213. [CrossRef]

21. Zemp, M.; Huss, M.; Thibert, E.; Eckert, E.; McNabb, R.; Huber, J.; Barandun, M.; Machguth, H.; Nussbaumer, S.U.; Gärtner-Roer, I.; et al. Global glacier mass changes and their contributions to sea-level rise from 1961 to 2016. Nature 2019, 568, 382-386. [CrossRef]

22. Baraer, M.; Mark, B.G.; McKenzie, J.M.; Condom, T.; Bury, J.; Huh, K.-I.; Portocarrero, C.; Gómez, J.; Rathay, S. Glacier Recession and Water Resources in Peru's Cordillera Blanca. J. Glaciol. 2012, 58, 134-150. [CrossRef]

23. Ragettli, S.; Immerzeel, W.W.; Pellicciotti, F. Contrasting climate change impact on river flows from high-altitude catchments in the Himalayan and Andes Mountains. Proc. Nat. Acad. Sci. USA 2016, 113, 9222-9227. [CrossRef] [PubMed]

24. Polk, M.H.; Young, K.R.; Baraer, M.; Mark, B.G.; McKenzie, J.M.; Bury, J.; Carey, M. Exploring Hydrologic Connections between Tropical Mountain Wetlands and Glacier Recession in Peru's Cordillera Blanca. Appl. Geogr. 2017, 78, 94-103. [CrossRef]

25. Jacobsen, D.; Milner, A.M.; Brown, L.E.; Dangles, O. Biodiversity under threat in glacier-fed river systems. Nat. Clim. Chang. 2012, 2,361-364. [CrossRef]

26. Cauvy-Fraunié, S.; Andino, P.; Espinosa, R.; Calvez, R.; Jacobsen, D.; Dangles, O. Ecological responses to experimental glacierrunoff reduction in alpine rivers. Nat. Comm. 2016, 7, 12025. [CrossRef]

27. Milner, A.M.; Khamis, K.; Battin, T.J.; Brittain, J.E.; Barranda, N.E.; Füreder, L.; Cauvy-Fraunie, S.; Gíslason, G.M.; Jacobsen, D.; Hannah, D.M.; et al. Glacier shrinkage driving global changes in downstream systems. Proc. Nat. Acad. Sci. USA 2017, 114, 9770-9778. [CrossRef]

28. Huss, M.; Bookhagen, B.; Huggel, C.; Jacobsen, D.; Bradley, R.S.; Clague, J.J.; Vuille, M.; Buytaert, W.; Cayen, D.R.; Greenwood, G.; et al. Toward mountains without permanent snow and ice. Earths Future 2017, 5, 418-435. [CrossRef]

29. Vuille, M.; Carey, M.; Huggel, C.; Buytaert, W.; Rabatel, A.; Jacobsen, D.; Soruco, A.; Villacis, M.; Yarleque, C.; Elison-Timm, O.; et al. Rapid decline of snow and ice in the tropical Andes-Impacts, uncertainties and challenges ahead. Earth Sci. Rev. 2018, 176, 195-213. [CrossRef]

30. Milner, A.M.; Robertson, A.L.; Brown, L.E.; Sønderland, S.H.; McDermott, M.; Veal, A.J. Evolution of a stream ecosystem in recently deglaciated terrain. Ecology 2011, 92, 1924-1935. [CrossRef]

31. Sertic Peric, M.; Jolidon, C.; Uehlinger, U.; Robinson, C.T. Long-term ecological patterns of alpine streams: An imprint of glacial legacies. Limnol. Oceanogr. 2015, 60, 992-1007. [CrossRef]

32. Rossaro, B.; Montagna, M.; Lencioni, V. Environmental traits affect chironomid communities in glacial areas of the Southern Alps: Evidence from a long-lasting case study. Insect Conserv. Divers. 2016, 9, 192-201. [CrossRef]

33. Lencioni, V. Glacial influence and stream macroinvertebrate biodiversity under climate change: Lessons from the Southern Alps. Sci. Tot. Env. 2018, 622-623, 563-575. [CrossRef]

34. Cauvy-Fraunié, S.; Dangles, O. A global synthesis of biodiversity responses to glacier retreat. Nat. Ecol. Evol. 2019, 3, 1675-1685. [CrossRef] [PubMed]

35. Niedrist, G.H.; Füreder, L. Trophic ecology of alpine stream invertebrates: Current status and future research needs. Freshw. Sci. 2017, 36, 466-478. [CrossRef]

36. Jacobsen, D.; Dangles, O.; Andino, P.; Espinosa, R.; Hamerlík, L.; Cadier, E. Longitudinalzonation of macroinvertebrates in an Ecuadorian glacier-fed stream: Do tropical glacial systems fit the temperate model? Freshw. Biol. 2010, 55, 1234-1248. [CrossRef]

37. Kuhn, J.; Andino, P.; Calvez, R.; Espinosa, R.; Hamerlík, L.; Vie, S.; Dangles, O.; Jacobsen, D. Spatial variability in macroinvertebrate assemblages along and among neighboring equatorial glacier-fed streams. Freshw. Biol. 2011, 56, 2226-2244. [CrossRef]

38. Espinosa, R.; Andino, P.; Cauvy-Fraunié, S.; Dangles, O.; Jacobsen, D.; Crespo-Pérez, V. Diversity patterns of aquatic macroinvertebrates across stream types and glacial influence in a tropical high-Andean catchment. Biol. Trop. 2020, 68, 39-53.

39. Crespo-Pérez, V.; Dangles, O.; Ibarra, C.; Espinosa, R.; Andino, P.; Jacobsen, D.; Cauvy-Fraunié, S. Functional structure and diversity of invertebrate communities in a glacierized catchment of the tropical Andes. Freshw. Biol. 2020, 65, 1348-1362. [CrossRef]

40. Cauvy-Fraunié, S.; Condom, T.; Rabatel, A.; Villacis, M.; Jacobsen, D.; Dangles, O. Technical note: Glacier influence in tropical mountain hydrosystems evidenced by the diurnal cycle in water level. Hydrol. Earth Syst. Sci. 2013, 17, 4803-4816. [CrossRef]

41. Jacobsen, D.; Andino, P.; Calvez, R.; Cauvy-Fraunié, S.; Espinosa, R.; Dangles, O. Temporal variability in discharge and benthic macroinvertebrate assemblages in a tropical glacier-fed stream. Freshw. Sci. 2014, 33, 32-45. [CrossRef]

42. Hongve, D. A revised procedure for discharge measurements by means of the salt dilution method. Hydrol. Proc. 1987, 1, 267-270. [CrossRef]

43. Pfankuch, D.J. Stream Reach Inventory and Channel Stability Evaluation; US Department of Agriculture Forest Service: Missoula, MO, USA, 1975.

44. Favier, V.; Coudrain, A.; Cadier, E.; Francou, B.; Ayabaca, E.; Maisincho, L.; Pradeiro, E.; Villacis, M.; Wagnon, P. Evidence of ground water flow on Antisana ice-covered volcano, Ecuador. Hydrol. Sci. J. 2008, 53, 278-291. [CrossRef]

45. Cauvy-Fraunié, S.; Espinosa, R.; Andino, P.; Jacobsen, D.; Dangles, O. Invertebrate Metacommunity Structure and Dynamics in an Andean Glacial Stream Network Facing Climate Change. PLoS ONE 2015. [CrossRef] [PubMed]

46. Graham, A.A.; McCaughan, D.J.; McKee, F.E. Measurement of surface area of stones. Hydrobiologia 1988, 157, 85-87. [CrossRef] 
47. Domínguez, E.; Fernández, H.R. (Eds.) Macroinvertebrados Bentónicos Sudamericanos: Sistemática y Biología; Fundación Miguel Lillo: Tucumán, Argentina, 2009.

48. Tomanova, S.; Goitia, E.; Helešic, J. Trophic levels \& functional feeding groups of macroinvertebrates in neotropical streams. Hydrobiologi 2006, 556, 251-264.

49. Tomanova, S.A.; Moya, N.; Oberdorff, T. Using macroinvertebrate biological traits for assessing biotic integrity of neotropical streams. River. Res. Appl. 2008, 24, 1230-1239. [CrossRef]

50. Merritt, R.W.; Cummins, K.W. An Introduction to the Aquatic Insects of North America, 3rd ed.; Knedall/Hunt Publishing Company: Dubuque Iowa, IA, USA, 1996.

51. Motta, R.L.; Uieda, V.S. Diet and trophic groups of an aquatic insect community in a tropical stream. Braz. J. Biol. 2003, 64, 809-817. [CrossRef]

52. Bouchard, R.W., Jr. Guide to the Aquatic Macroinvertebrates of the Upper Midwest; Water Resources Center, University of Minnesota: St. Paul, MN, USA, 2004.

53. Rivera, J.J.; Pinilla, G.; Camacho, D.L. Macroinvertebrate Trophic Groups in an Andean Wetland of Colombia. Acta. Biol. Colom. 2013, 18, 279-292.

54. Dangles, O. Functional plasticity of Benthic macroinvertebrates: Implications for trophic dynamics in acid streams. Can. J. Fish Aqua Sci. 2002, 59, 1-11. [CrossRef]

55. Ramírez, A.; Gutiérrez-Fonseca, P.E. Functional feeding groups of aquatic insect families in Latin America: A critical analysis and review of existing literature. Intern. J. Trop. Biol. 2014, 62, 155-167. [CrossRef]

56. Dangles, O.; Crespo-Pérez, V.; Andino, P.; Espinosa, R.; Calvez, R.; Jacobsen, D. Predicting richness effects on ecosystem function in natural communities: Insights from high-Elevation streams. Ecology 2011, 92, 733-743. [CrossRef] [PubMed]

57. Webster, J.R.; Benfield, E.F. Vascular plant breakdown in freshwater ecosystems. Ann. Rev. Ecol. Syst. 1986, 17, 567-594. [CrossRef]

58. Bärlocher, F. Leaf Mass Loss Estimated by Litter Bags Technique. In Methods to Study Litter Decomposition. A Pratical Guide; Graça, M.A.S., Bärlocher, F., Gessner, M.O., Eds.; Springer: Dordrecht, The Netherlands, 2005; pp. 37-42.

59. Benfield, E.F. Decomposition of leaf material. In Methods in Stream Ecology, 2nd ed.; Hauer, F.R., Lamberti, G.A., Eds.; Elsevier: New York, NY, USA, 2006; pp. 711-720.

60. Ferreira, V.; Gulis, V.; Graça, M.A.S. Whole-stream nitrate addition aVects litter decomposition and associated fungi but not invertebrates. Oecologia 2006, 149, 718-729. [CrossRef]

61. Hammer, Ø.; Harper, D.A.T.; Ryan, P.D. Past: Paleontological Statistics Software Package for Education and Data Analysis. Palaeontol. Electron. 2001, $4,4$.

62. Lencioni, V.; Rossaro, B. Microdistribution of chironomids (Diptera: Chironomidae) in Alpine streams: An autoecological perspective. Hydrobiologia 2005, 533, 61-76. [CrossRef]

63. Rott, E.; Cantonati, M.; Füreder, L.; Pfister, P. Benthic algae in high altitude streams of the Alps-A neglected component of the aquatic biota. Hydrobiologia 2006, 562, 195-216. [CrossRef]

64. McKernan, C.; Cooper, D.J.; Schweiger, E.W. Glacial loss and its effect on riparian vegetation of alpine streams. Freshw. Biol. 2018, 63, 518-529. [CrossRef]

65. Cariss, H.; Dobson, M. Transport and retention of detritus in upland streams: A comparison of an open stream and an adjacent wooded site. Limnetica 1997, 13, 85-91.

66. Biggs, B.J.F.; Smith, R.A.; Duncan, M.J. Velocity and sediment disturbance of periphyton in headwater streams: Biomass and metabolism. J. N. Am. Benthol. Soc. 1999, 18, 222-241.

67. Lemly, A.D.; Hilderbrand, R.H. Influence of large woody debris on stream insect communities \& benthic detritus. Hydrobiologia 2000, 421, 179-185.

68. Cauvy-Fraunié, S.; Espinosa, R.; Andino, P.; Dangles, O.; Jacobsen, D. Relationships between stream macroinvertebrate communities and new flood-based indices of glacial influence. Freshw. Biol. 2014, 59, 1916-1925. [CrossRef]

69. Scotti, A.; Füreder, L.; Marsoner, T.; Tappeiner, U.; Stawinoga, A.E.; Bottarin, R. Effects of land cover type on community structure and functional traits of alpine stream benthic macroinvertebrates. Freshw. Biol. 2020, 65, 524-539. [CrossRef]

70. Allan, J.D.; Castillo, M.M. Stream Ecology: Structure and Function of Running Waters; Springer: Berlin/Heidelberg, Germany, 2007. 